\title{
OPINIE POZNANIAKÓW \\ O OBECNOŚCI OBCOKRAJOWCÓW NA RYNKU PRACY W ŚWIETLE MIGRACJI KOMPENSACYJNYCH DO POLSKI
}

\section{WSTEP}

Procesy ruchliwości przestrzennej oparte na względnie trwałych (stałych lub czasowych) zmianach miejsca pobytu jednostek w ramach pewnej przestrzeni wpisane są w obszar refleksji kilku dyscyplin naukowych, z demografia oraz socjologia na czele. O ile jednak demografowie postrzegają migrację jako jeden z trzech głównych czynników (obok zgonów oraz urodzeń) zmiany składu ilościowego populacji (przyrost rzeczywisty), o tyle przedstawiciele socjologii koncentrują uwagę na aspektach jakościowych, patrząc na wewnątrzkrajowe lub międzykrajowe przemieszczenia się ludności z perspektywy uczestniczących $\mathrm{w}$ nim aktorów. Stykając się z fenomenem migracji, socjolog zwraca uwagę przede wszystkim na: 1) motywy skłaniające jednostki do podjęcia decyzji o migracji, poczucie obcości, doświadczane przejawy wrogości i ksenofobii, problemy adaptacyjne i integracyjne imigrantów, 2) oczekiwania asymilacyjne ze strony społeczności ,,przyjmującej” migrantów, otwartość struktury społecznej, poziomą i pionową ruchliwość społeczną, możliwość osiągania społecznie ważnych celów życiowych, 3) skutki migracji w postaci pojawienia się enklaw imigranckich mniejszości narodowych, wzrost bezrobocia, rozrost szarej strefy gospodarki, pojawienie się nowych typów zjawisk kryminogennych, niepewność, ryzyko, rozpad więzi itd., 4) makrostrukturalne skutki migracji w postaci ubytku lub napływu znaczących grup ludności, 5) prawne oraz polityczno-instytucjonalne aspekty migracji.

Zaprezentowane w niniejszym artykule analizy maja charakter fragmentaryczny, nie roszczę sobie pretensji do mówienia o społecznych uwarunkowaniach bądź konsekwencjach procesów migracyjnych. Nie staram się osadzić prowadzonych rozważań $\mathrm{w}$ ramach jakiejś wybranej socjologicznej koncepcji ruchliwości przestrzennej, wielokulturowości, socjologii miasta, czy też teorii migracji w ogóle. Nie definiuję pojęcia migracji oraz nie wprowadzam rozróżnień teoretycznych pomiędzy emigracją a imigracją - wszystkie te pojęcia są znane, ich dokładna charakterystyka wraz z ,wyrafinowanymi” rozróżnieniami pojęciowymi nie wniosłyby niczego nowego do przeprowadzonych analiz. Co więcej, przedmiotem mojego zainteresowania nie są nawet sami cudzoziemcy, jako że swoja uwagę skupiam głównie na poznaniakach oraz 
wybranych komponentach ich lokalnej tożsamości i obyczajowości, które w moim przekonaniu - są czynnikami wzmacniającymi lub osłabiającymi poziom społecznej akceptacji dla obecności obcokrajowców w Polsce. Uważam (i staram się tezy tej bronić), że wyrażane przez poznaniaków opinie na temat możliwości osiedlania się obcokrajowców oraz podejmowania przez nich pracy w Polsce są odwzorowaniem swoistej mieszanki: z jednej strony - gospodarczej otwartości mieszkańców Poznania, a z drugiej - ich kulturowej zachowawczości. Innymi słowy, tradycyjna tożsamość regionalna zdecydowanie bardziej predysponuje poznaniaków do otwartości na nowości w sferze gospodarki i pracy niż w sferze kultury i obyczajów, co postaram się wykazać, analizując rozkłady opinii mieszkańców Poznania na temat cudzoziemców.

W kontekście rozpatrywanych tu ekonomicznych oraz społeczno-kulturowych aspektów imigracji obcokrajowców do Polski warto zwrócić uwagę na fakt, że liczba osób osiedlających się w województwie wielkopolskim (na stałe lub czasowo) kształtuje się na poziomie zdecydowanie poniżej średniej krajowej. Głównym celem migracji w Wielkopolsce pozostaje Poznań wraz z powiatem poznańskim, w mniejszym stopniu Kalisz, natomiast w pozostałych wielkopolskich powiatach liczba imigrantów osiaga wartości najniższe w skali całego kraju ${ }^{1}$. Według danych z Narodowego Spisu Powszechnego Ludności przeprowadzonego w 2002 r., najliczniejszą grupę imigrantów osiedleńczych i czasowych w Wielkopolsce stanowili Ukraińcy, Rosjanie oraz Białorusini, jednakże od wejścia Polski do UE w 2004 r. struktura narodowości przybyszów ulega stałym przekształceniom. W ostatnich latach wyraźnie wzrasta liczba cudzoziemców z państw ,starej” UE, przy jednoczesnym spadku liczby imigrantów z krajów byłego bloku ZSRR ${ }^{2}$. Wprawdzie w 2006 r. najliczniejszą grupę osób osiedlających się w Wielkopolsce stanowili nadal imigranci pochodzenia ukraińskiego, jednakże na drugim miejscu uplasowali się już przybysze narodowości niemieckiej ${ }^{3}$.

Napływ obcokrajowców do Polski wywołany jest specyficznym typem migracji, nazywanej w literaturze przedmiotu migracja kompensacyjna ${ }^{4}$. Przez termin ten rozumie się takie międzykrajowe przemieszczenia ludności, które neutralizuja negatywne skutki zwiazane $\mathrm{z}$ malejąca populacja kraju docelowego, w tym na przykład niedobór zasobów ludzkich na rynku pracy ${ }^{5}$.

\footnotetext{
${ }^{1}$ J. Napierała, Podstawowe charakterystyki emigracji i imigracji, w: E. Jaźwińska-Motylska (red.), Imigracja do Polski w świetle wyników Narodowego Spisu Powszechnego 2002, Centrum Badań nad Migracjami, Warszawa 2006, s. 9.

${ }^{2}$ E. Kępińska, Recent Trends in International Migration. The 2007 SOPEMI Report for Poland, „CEFMR Working Papers” 2007, nr 29/(87), s. 12.

${ }^{3}$ Ibidem, s. 56.

${ }^{4}$ K. Saczuk, A Development and Critique of the Concept of Replacement Migration, „CEFMR Working Papers" 2003, nr 4, s. 4.

${ }^{5} \mathrm{~W}$ literaturze przedmiotu podważa się rzeczywistą skuteczność kompensacyjnych przemieszczeń ludności jako rozwiązania problemów demograficznych państw rozwiniętych. Jako przykład można podać dyskusję wokół wpływu migracji kompensacyjnych na wydajność systemu emerytalnego. Wielu demografów podkreśla, że bardziej racjonalną decyzją byłoby dostosowanie rowiązań systemowych do zmieniających się warunków demograficznych populacji, aniżeli utrzymywanie niewydolnych systemów. Por. L. F. Bouvier, Replacement Migration. Is It Solution to Declining and Aging Population?, „Population and Environment” 22, 2001, nr 4, s. 371-381.
} 
Mówiąc o migracjach kompensacyjnych oraz opiniach poznaniaków o napływie obcokrajowców do Polski, będę miał na uwadze tylko taki typ imigracji, który związany jest z motywowanymi zarobkowo decyzjami obcokrajowców o przyjeździe i zamieszkaniu w Polsce. Poza kręgiem zainteresowania pozostaną też takie istotne zagadnienia, jak to, czy migracje takie sa rzeczywiście efektem jakiejś polityki zmierzającej do poprawy kapitału ludzkiego społeczności oraz czy w ogóle przyczyniaja się do społecznej, ekonomicznej i demograficznej poprawy struktury populacji ${ }^{6}$.

Biorąc zatem pod uwagę migracje zarobkowe, można zaobserwować dwie kategorie obcokrajowców przybywających do pracy w Polsce. Z krajów UE napływaja głównie menadżerowie oraz kadra kierownicza, natomiast z państw Europy Wschodniej robotnicy wykwalifikowani oraz niewykwalifikowani ${ }^{7}$. Dane statystyczne dotyczące zatrudniania imigrantów ukazuja ponadto, że obcokrajowcy osiedlający się w Polsce zapełniają luki na runku pracy, podejmując aktywność $\mathrm{w}$ tych sektorych, które pozostaja nieobsadzone przez Polaków - bądź z powodów braku odpowiednich specjalistów, bądź też z niechęci do podejmowania niskopłatnych prac związanych z zawodami uznawanymi za mało prestiżowe ${ }^{8}$.

W kontekście przekonań poznaniaków o możliwości osiedlania się obcokrajowców w Polsce należy w pierwszej kolejności zauważyć, że współczesne doświadczenia migracyjne mieszkańców Poznania nie obejmuja napływu znacznych grup ludności definiowanych jako obce kulturowo lub obyczajowo. Poznań od lat jest celem dla ludności z innych regionów kraju - definiowanej jako ,inna”, ale nie „obca”. W tym sensie struktura społeczna cechowała się takim poziomem otwartości, który wymagany jest dla skutecznej adaptacji społeczno-ekonomicznej przybyszów z peryferyjnych regionów Wielkopolski oraz innych regionów Polski. Jednocześnie jednak nawet w wypadku ludności napływowej niewykazującej zasadniczej obcości kulturowej rejestrowano liczne trudności adaptacyjne, a także wyraźne naciski na asymilację do lokalnej obyczajowości i tożsamości ${ }^{9}$.

Biorąc pod uwagę współczesne trendy demograficzne w Polsce, trudno przypuszczać, by wewnątrzkrajowi migranci mogli nadal rekompensować braki na lokalnym rynku pracy. Podstawowa różnica w starych i nowych migracjach kompensacyjnych polega więc na tym, że wewnątrzkrajowi migranci wymagali przede wszystkim integracji ekonomicznej, natomiast w wypadku migrantów międzynarodowych należy spodziewać się występowania oporu wobec

${ }^{6} \mathrm{~W}$ świetle ogólnokrajowych danych statystycznych oraz opracowań naukowych poświęconych problematyce migracji kompensacyjnych widać, że wśród obcokrajowców przybywających do Polski przeważają osoby w wieku produkcyjnym oraz dysponujące lepszym kapitałem społecznym aniżeli te, które opuszczają Polskę. Z tego względu imigracje do Polski jawią się jako czynnik poprawy kapitału ludzkiego. Por. M. Okólski, Zasoby ludzkie i kapitat ludzki (human capital) imigrantów, w: E. Jaźwińska-Motylska (red.), op. cit., s. 23-25.

${ }^{7}$ P. Kaczmarczyk, Cudzoziemscy pracownicy w Polsce - skala, struktura, znaczenie dla polskiego rynku pracy, w: P. Kaczmarczyk, M. Okólski (red.), Polityka migracyjna jako instrument promocji zatrudnienia i ograniczania bezrobocia, Centrum Badań nad Migracjami, Warszawa 2006, s. 56.

${ }^{8}$ Ibidem, s. 52.

${ }^{9}$ Por. R. Cichocki, K. Podemski, Miasto w świadomości swoich mieszkańców, Wyd. Fundacji Humaniora, Poznań 1999, s. 19-58. 


\section{Rysunek 1}

Społeczne postawy wobec „obcych” i ,,innych” - schemat teoretyczno-metodologiczny

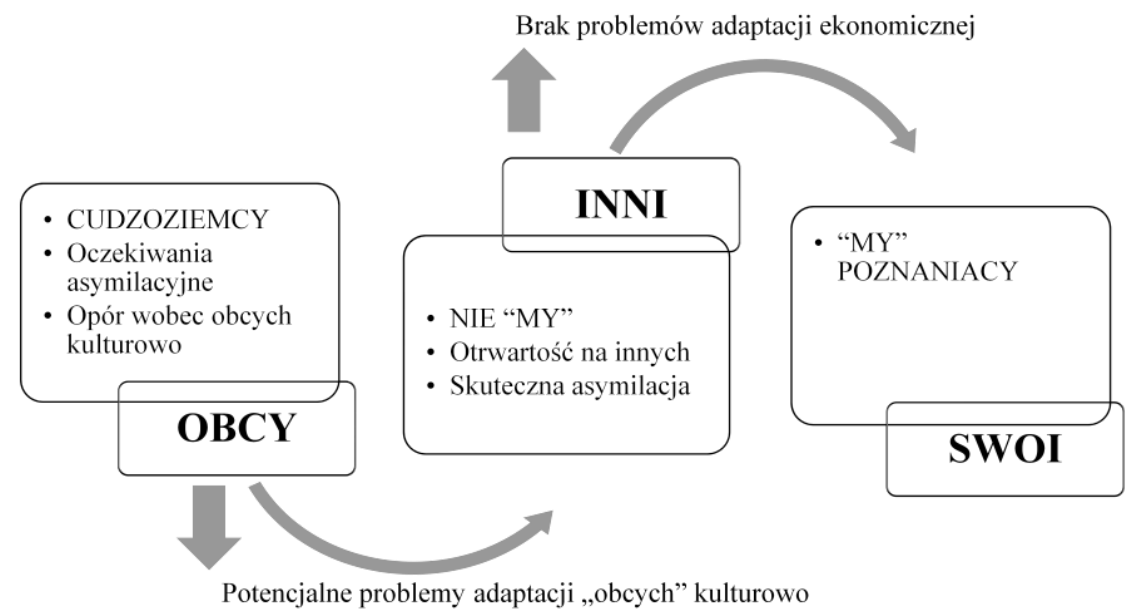

odmienności obyczajowej i kulturowej przybyszów. Niechęć wobec kulturowej obcości może zatem potencjalnie dominować nad gospodarczą otwartością na nową siłę robocza, utrudniając przez to integrację społeczną ludności napływowej ${ }^{10}$. Definiowanie lokalnej tożsamości poznaniaków może zostać zdominowane przez opór wobec „obcych”, choć pewien wpływ na zmianę opinii moga mieć także migracje powrotne Polaków z krajów Europy Zachodniej. Niemniej jednak, obserwując trwałość mentalności rejestrowana w zakresie przywiązania do tradycyjnych form kulturowych oraz niechęć do demonstrowania odmienności w przestrzeni publicznej, należy spodziewać się raczej dominacji oczekiwań asymilacyjnych w odniesieniu do obcych kulturowo przybyszów.

Przedmiotem analiz zaprezentowanych $\mathrm{w}$ artykule będa wywołane procesami migracji kompensacyjnych opinie poznaniaków formułowane $\mathrm{w}$ odniesieniu do obecności obcokrajowców na polskim rynku pracy. Przedstawione wyniki są częścią projektu badawczego „Poziom zaufania mieszkańców Poznania do obcokrajowców i jego uwarunkowania”, realizowanego od października 2009 do września 2010 r. Część empiryczna programu opierała się na dwóch komplementarnych pomiarach: 1) wywiadzie kwestionariuszowym PAPI zrealizowanym na imiennej losowej próbie 436 mieszkańców Poznania, 2) pogłębionych wywiadach indywidualnych z celowo dobranymi poznaniakami, którzy utrzymywali jakieś kontakty z obcokrajowcami przebywającymi w Polsce.

Przedstawione $\mathrm{w}$ artykule rozważania maja bardziej charakter eksploracyjny niż wyjaśniający i opierają się głównie na wynikach pomiaru ilościowego.

\footnotetext{
${ }^{10}$ Obyczajowy konserwatyzm przypisywany jest długotrwałemu wpływowi światopoglądu ukształtowanego pod zaborem pruskim, którego następstwem było odrzucanie wzorów kulturowych definiowanych jako obce; por. J. T. Hryniewicz, Polityczne i gospodarcze nastepstwa zaboru pruskiego, „Studia Regionalne i Lokalne” 2003, nr 3, s. 61-78.
} 
Ponadto, zawężając badana populację do mieszkańców Poznania, dają jedynie obraz opinii mieszkańców regionalnego centrum i nie moga stanowić podstaw do uogólnień w odniesieniu do całej społeczności Wielkopolski. Zarysowany $\mathrm{w}$ ten sposób obraz naznaczony byłby poznaniocentryczną wizją społeczeństwa wielkopolskiego ${ }^{11}$, chociażby ze względu na niski poziom bezrobocia odnotowywany w Poznaniu, mniejsze społeczne obawy o utratę miejsc pracy wyrażane przez poznaniaków w stosunku do obaw deklarowanych przez Wielkopolan zamieszkujących peryferyjne obszary województwa ${ }^{12}$, a także generalnie większą aprobatę co do możliwości pracy cudzoziemców wyrażaną przez mieszkańców dużych polskich miast ${ }^{13}$. W niniejszej pracy uwagę skupiono głównie na opiniach mieszkańców Poznania o obcokrajowcach, a dane statystyki publicznej pozwalaja jedynie na scharakteryzowanie skali międzykrajowych imigracji na poziomie województwa ${ }^{14}$.

\section{OPINIE POZNANIAKÓW O OBECNOŚCI OBCOKRAJOWCÓW NA RYNKU PRACY W POLSCE}

Stanowiące element diagnozy przekonań mieszkańców Poznania pytanie o możliwości podejmowania przez obcokrajowców pracy dotyczyło tego, czy w opinii respondentów powinno się zezwolić cudzoziemcom na pracę w Polsce. Badanym osobom przedstawiono do wyboru jedną $\mathrm{z}$ trzech możliwych odpowiedzi: 1) „Powinno się pozwolić na podjęcie każdej pracy”, 2) „Powinno się pozwolić na podjęcie jedynie niektórych rodzajów prac”, 3) „W ogóle nie powinno się pozwalać pracować obcokrajowcom w Polsce”. Jeżeli badana osoba wahała się i nie była zdecydowana w swojej opinii, ankieter zaznaczał opcje ,,Trudno powiedzieć”. Na wykresie 1 zaprezentowano rozkład częstości odpowiedzi na zadane pytanie.

Przedstawione dane ukazują, że wyrażona przez poznaniaków akceptacja obecności obcokrajowców na rynku pracy w Polsce jest powszechna, przy czym ponad $60 \%$ badanych uważa, że cudzoziemcom powinno się pozwolić na wykonywanie każdej pracy, natomiast nieco ponad $26 \%$ mieszkańców wyraża pogląd, że osobom z zagranicy powinno się pozwolić na wykonywanie jedynie

11 „Poznaniocentryzm” analiz, czyli wnioskowanie o cechach mentalności Wielkopolan na podstawie badań poznaniaków, był jednym z trzech głównych problemów, na które wskazywałem wspólnie z Piotrem Cichockim jako na zasadnicze ograniczenie poznawcze współczesnej refleksji socjologicznej nad wielkopolskim społeczeństwem; por. P. Cichocki, P. Jabkowski, Przemiany poczucia satysfakcji życiowej Wielkopolan, ,Ruch Prawniczy Socjologiczny i Ekonomiczny” 2009, z. 3, s. 175-183.

12 Społeczne dysproporcje w deklarowanych obawach o utratę miejsc pracy opisałem wraz z P. Cichockim w monografii referującej wyniki badań nad opiniami Wielkopolan wobec obecności Polski w UE; por. P. Cichocki, P. Jabkowski, Wielkopolska - regionalny kontekst integracji europejskiej, Wydawnictwo Naukowe UAM, Poznań 2010, s. 84-95.

${ }^{13}$ Por. Praca cudzoziemców w Polsce, Raport CBOS nr BS/148/2010, s. 6 (http://www.cbos.pl).

${ }^{14}$ Odpowiednie dane na poziomie powiatu lub gminy dostępne są jedynie dla lat, w których przeprowadzono spisy powszechne. Dla przykładu, w wydanej w 2010 r. publikacji poświęconej imigracjom obcokrajowców do Polski analizy międzypowiatowych zróżnicowań w narodowości cudzoziemców osiedlających się w Polsce opierają się nadal na danych z 2002 r.; por. A. Górny, I. Grabowska-Lusińska, M. Lesińska, M. Okólski (red.), Immigration to Poland: Policy, Employment, Integration, Scholar, Warszawa 2010, s. 241. 


\section{Wykres 1}

Rozkład akceptacji obecności obcokrajowców na rynku pracy w Polsce

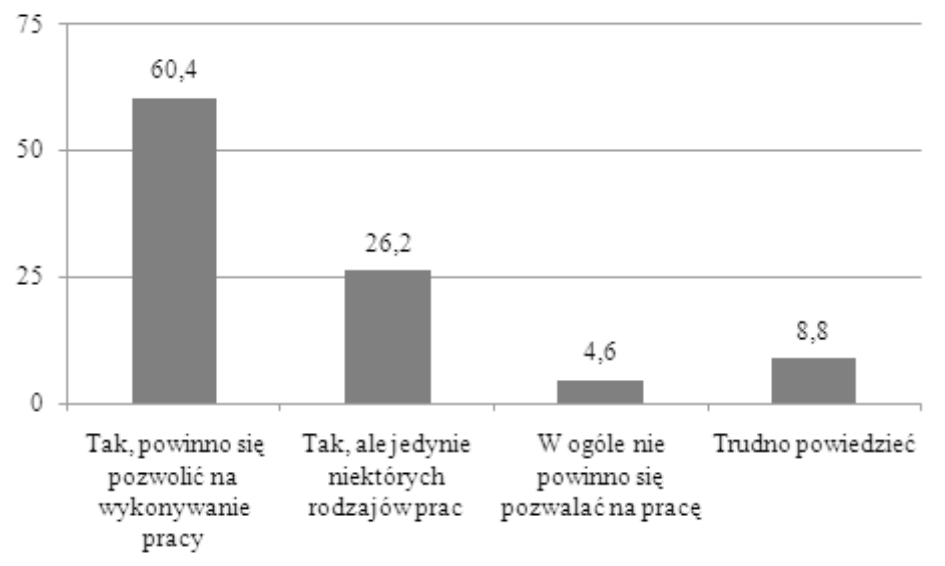

niektórych rodzajów prac. Warto podkreślić, że rozkład opinii uzyskany wśród mieszkańców Poznania pozostaje praktycznie zbieżny z wynikami pomiarów przeprowadzanych na próbach ogólnopolskich (na przykład w badaniach CBOS-u z 2010 r. ${ }^{15}$ ), przy czym poznaniacy wykazuja nieco większą aprobatę dla możliwości pracy cudzoziemców w każdym zawodzie.

Niemniej jednak z uzyskanych rozkładów opinii wyraźnie zarysowuje się potencjalny opór poznaniaków wobec imigrantów definiowanych jako obcy kulturowo. Wprawdzie Polska nie jest celem migracji osiedleńczych dużej liczby osób z krajów azjatyckich, muzułmańskich czy też państw „,czarnej Afryki” (nasz kraj stanowi jedynie punkt przejściowy w migracji do krajów ,,starej” Unii Europejskiej), ale w perspektywie najbliższych kilkudziesięciu lat nie da się wykluczyć znaczącego wzrostu liczby imigrantów z krajów pozaeuropejskich. Przebiegające w tym kierunku przekształcenia struktury narodowościowej imigrantów mogą zatem wywołać społeczną niechęć poznaniaków wobec obcych przybyszów, mimo że nie zauważa się jej obecnie na dużą skalę. Niechęć wobec odmienności kulturowej migrantów wyraża się przy tym w niskim przyzwoleniu na publiczną ekspresję przez obcokrajowców takich ich zwyczajów, które pozostaja odmienne od tradycyjnie definiowanych w Polsce norm kulturowo-obyczajowych. Ustalenia te pozostaja zgodne z cechami tradycyjnie przypisywanymi mentalności Wielkopolan (w tym również poznaniaków), a więc gospodarczą otwartością oraz kulturowo-obyczajową zachowawczością ${ }^{16}$. Wskaźnikiem owej zachowawczości jest między innymi relatywnie dużo niższy niż

${ }^{15} \mathrm{~W}$ przywoływanych badaniach $81 \%$ Polaków wyraża pozytywną opinię o możliwości zatrudniania obcokrajowców; por. Praca cudzoziemców..., s. 6.

${ }^{16}$ Dla przykładu, w tekście M. Ziółkowskiego znajdziemy dychotomię podkreślającą - z jednej strony - ,wielkopolską gospodarność i przedsiębiorczość”, a z drugiej - ,wielkopolskie przywiązanie do tradycji”; por. M. Ziółkowski, Mentalność Wielkopolan: rzeczywistość, stereotyp czy perswazyjne argumenty, „Przegląd Zachodni” 1999, nr 4, s. 11-30. 
w stosunku do cudzoziemców z krajów UE poziom aprobaty dla obecności „obcych” pochodzących z krajów muzułmańskich i ,czarnej” Afryki ${ }^{17}$, wobec których mieszkańcy Poznania przejawiają jednocześnie najwyższą nieufność ${ }^{18}$.

Dwubiegunowy charakter opinii poznaniaków o obcokrajowcach znalazł odzwierciedlenie w wywiadach pogłębionych, prowadzonych z celowo dobranymi mieszkańcami miasta ${ }^{19}$. Z jednej strony uczestnicy wywiadów wielokrotnie wyrażali swój pozytywny stosunek do możliwości podejmowania w Polsce pracy przez obcokrajowców z Europy Zachodniej i Stanów Zjednoczonych, przypisując osiedlającym się w naszym kraju obywatelom państw zachodnich pozytywne cechy (wysoki poziom kultury osobistej, zamożność, pracowitość, wyższy poziom wykształcenia):

Ja kojarzę tych, którzy są z Zachodu, a nie ze Wschodu [...], zamożnych ze Stanów Zjednoczonych, ze Skandynawii, którzy przyjeżdżają tutaj na studia, albo do pracy. [...] I kojarzy mi się, że to są ludzie zazwyczaj z jakimś dobrym zaopatrzeniem finansowym [...] i z takimi aspiracjami raczej intelektualnymi, są zazwyczaj wykształceni [...]. Jeśli tutaj pracuja, to często na kierowniczych stanowiskach [...], sa dyrektorami firm, przyjeżdżają tutaj na audyty albo na spotkania biznesowe. W tym momencie to nie jest przeciętny człowiek, tylko człowiek wyższej klasy.

(Wypowiedź kobiety w wieku 25 lat, przewodniczki po Poznaniu).

Z drugiej strony respondenci wyraźnie dystansowali się od obywateli państw Europy Wschodniej ${ }^{20}$ oraz krajów definiowanych jako obce kulturowo. Z wypowiedzi badanych osób można wywnioskować, że praca cudzoziemców z krajów azjatyckich kojarzona jest przede wszystkim z usługami gastronomicznymi, natomiast działalność zarobkowa przybyszów z krajów Europy Wschodniej lokowana jest głównie w szarej strefie polskiej gospodarki:

To jest ta sympatyczniejsza grupa [tu mowa o obcokrajowcach z państw zachodniej Europy - P.J.], ale jest jeszcze druga grupa, czyli to sa tacy imigranci zarobkowi - to ta mroczna strona imigracji, jak wszędzie. W Polsce nie jest ich tak dużo, jak na Zachodzie, ale są ci wszyscy z barów chińskich, handlujący odzieżą i ta cała grupa ze Wschodu [...] trudniąca się mniej legalną działalnością.

(Wypowiedź mężczyzny w wieku 25 lat, studenta studiów doktoranckich).

${ }^{17}$ Poziom akceptacji osiedlania się w Polsce cudzoziemców z krajów UE oscyluje wokół 90 punktów procentowych; wobec czarnoskórych obcokrajowców z Afryki jest on o ponad 30 punktów procentowych niższy. Najrzadziej mamy do czynienia ze zgodą na przyjazd cudzoziemców z krajów muzułmańskich (niespełna 50 punktów procentowych).

${ }^{18}$ Równie znaczące dysproporcje ujawniono w wyrażanym przez poznaniaków poziomie zaufania do obcokrajowców. Respondentom przedstawiono listę krajów i zadano pytanie: czy w ich opinii można ufać obywatelom wymienionych państw? Przeciętny poziom zaufania wyrażany w stosunku do mieszkańców państw Zachodniej Europy wynosił ponad 70 punktów procentowych, podczas gdy w odniesieniu do mieszkańców państw muzułmańskich osiągnął wartość niespełna 37 punktów procentowych.

${ }^{19}$ Uczestników pogłębionych wywiadów indywidualnych dobierano ze względu na posiadane doświadczenia w kontaktach z obcokrajowcami przebywającymi w Polsce.

${ }^{20}$ Przywoływane w artykule badania CBOS-u nad postawami wobec pracy cudzoziemców w Polsce wskazują, że w 2010 r. wyraźnie wzrosło negatywne postrzeganie przybyszów z Białorusi, Ukrainy i Rosji; por. Praca cudzoziemców..., s. 7. Nie posiadam danych w ujęciu diachronicznym dla mieszkańców Poznania, które mogłyby potwierdzić taką tendencję, niemniej jednak wśród poznaniaków akceptacja obecności przybyszów z byłego bloku ZSRR jest dużo niższa niż w odniesieniu do obywateli państw zachodnich. 
Wśród osób biorących udział w wywiadach pogłębionych dominowało jednak przekonanie, że imigracja cudzoziemców z krajów biedniejszych jest procesem nieodwracalnym, chociażby ze względu na niedobór zasobów ludzkich w pewnych dziedzinach gospodarki oraz niechęć Polaków do wykonywania mniej prestiżowych prac. Pragmatyczna gospodarcza otwartość na nową siłę robocza dominowała w wielu wypowiedziach nad kulturową zachowawczością:

To znaczy ludzie, którzy przybywają do Polski powiedzmy z tych krajów wschodnich czy dalekowschodnich, stanowią na pewno konkurencję, z uwagi na niższe wymagania płacowe [...] i zawsze jest taka obawa, że będzie mniejszy rynek pracy, rodacy będa bezrobotni. No ale z drugiej strony, po prostu otwarliśmy swoje granice. Zdecydowaliśmy się na współpracę z Europą i całym światem. Uważam, że powinniśmy przyjąć tę konkurencję.

(Wypowiedź mężczyzny w wieku około 50 lat, pracownika prywatnej firmy).

Powracając jednak do wyników badań uzyskanych w ramach sondażu ilościowego, warto zauważyć, że przyzwolenie na podejmowanie przez obcokrajowców pracy w Polsce jest wśród poznaniaków silnie uzależnione nie tylko od wieku ${ }^{21}$ i wykształcenia respondentów ${ }^{22}$, lecz również - a może przede wszystkim - od posiadanych doświadczeń w kontaktach z osobami z zagranicy oraz od ogólnej postawy badanych wobec ,obcych”. Pozostaje to jednak w pełni zgodne $\mathrm{z}$ ustaleniami poczynionymi $\mathrm{w}$ ramach przywoływanych już badań CBOS-u, które ukazuja, że zarówno społeczno-demograficzne charakterystyki badanych, takie jak: młodszy wiek oraz wyższe wykształcenie, jak i inne uwarunkowania, na przykład fakt osobistej znajomości z obcokrajowcami, zwiększa akceptację ich obecności na polskim rynku pracy ${ }^{23}$.

Takie przykładowe zależności przedstawiono na dwóch kolejnych wykresach (2 i 3). Na pierwszym z nich ukazano, w jaki sposób opinia poznaniaków o możliwości podjęcia pracy przez imigrantów zagranicznych uwarunkowana jest od charakteru dotychczasowych kontaktów z obcokrajowcami, na drugim przedstawiono takie zróżnicowania $\mathrm{w}$ odniesieniu do cech moralnych

${ }^{21} \mathrm{~W}$ kategorii wiekowej osób do 20 roku życia poziom przyzwolenia na pracę obcokrajowców w dowolnym zawodzie wynosi prawie 73 punkty procentowe. Wartość tę wystarczy zestawić z poziomem akceptacji zaobserwowanym wśród osób w wieku powyżej 60 roku życia. W najstarszej wiekowo kategorii respondentów akceptację wyrażało bowiem niespełna $50 \%$ badanych. Uzyskane zróżnicowanie rozkładów jest istotne statystyczne, na co wskazuje test Fishera-Snedecora dla wielu wskaźników struktury: wartość statystyki testowej wyniosła $F=12,75$ z $d f=5 ;+\infty$, a poziom istotności statystyki testowej był mniejszy od założonego poziomu wnioskowania $\alpha=0,05$.

${ }^{22}$ Najniższym poziomem przyzwolenia na pracę cudzoziemców w Polsce charakteryzują się respondenci $\mathrm{z}$ wykształceniem podstawowym oraz zasadniczym zawodowym. W obu wymienionych kategoriach jedynie nieco ponad $45 \%$ badanych wyraża całkowitą aprobatę dla możliwości podejmowania pracy przez obcokrajowców, podczas gdy wśród osób z wykształceniem średnim oraz wyższym poziom ten oscyluje wokół 70 punktów procentowych. Uzyskane zróżnicowanie jest istotne w sensie statystycznym, co pokazuje wynik tego samego testu, który zastosowano do badania zróżnicowania ze względu na wiek badanych osób. Wartość statystyki testowej była w tym przypadku równa $F=16,32$ (przy liczbie stopni swobody $d f=3,+\infty$ ), co oznacza, że poziom istotności statystyki testowej był mniejszy od założonego poziomu wnioskowania.

${ }^{23}$ Por. Praca cudzoziemców..., s. 6. 


\section{Wykres 2}

Akceptacja podejmowania przez obcokrajowców pracy w Polsce a charakterystyka dotychczasowych kontaktów z obcokrajowcami

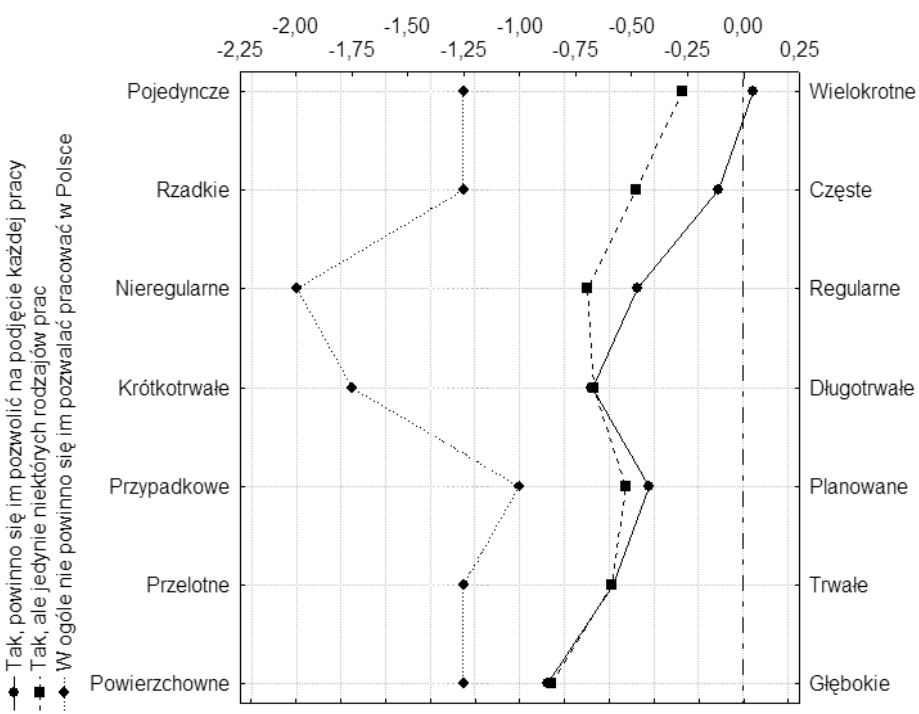

przypisywanych przybyszom $\mathrm{z}$ innych krajów ${ }^{24}$. Charakteryzując dotychczasowe kontakty mieszkańców Poznania z obcokrajowcami oraz cechy moralne przypisywane ,obcym”, wykorzystano pytania oparte na dyferencjale semantycznym, przedstawiając respondentom do wyboru zestawy przeciwstawnych stwierdzeń ${ }^{25}$.

Przyglądając się profilom odpowiedzi uzyskanym w obrębie trzech kategorii respondentów wyodrębnionych na podstawie deklarowanych opinii o możliwości pracy obcokrajowców w Polsce, można zauważyć, że osoby, które wyrażaja pozytywną opinię na ten temat, posiadają jednocześnie większe doświadczenie w bezpośrednich kontakach z osobami z zagranicy. Szczególnie duże dysproporcje uzyskano tutaj $\mathrm{w}$ odniesieniu do częstości, regularności oraz czasu trwania znajomości, czyli wymiarów charakterystyk dotychczasowych kontaktów najczęściej wskazywanych przez tych respondentów, którzy powołując się na okoliczności, w jakich spotykają obcokrajowców, wymieniali głównie swoje doświadczenia zawodowe.

${ }^{24} \mathrm{Na}$ obu wykresach (2 i 3) ukazane zostały profile odpowiedzi dla trzech kategorii respondentów: 1) wyrażających pełną aprobatę dla podejmowania pracy przez obcokrajowców, 2) wyrażających aprobatę częściowa, tzn. możliwości pracy jedynie w wybranych zawodach, 3) wyrażających brak aprobaty dla możliwości pracy obcokrajowców w Polsce. Wartości dodatnie oznaczają przy tym przewagę wyborów stwierdzeń po prawej stronie wykresów, ujemne natomiast na przewagę wyborów stwierdzeń zaprezentowanych w lewej kolumnie wykresów.

${ }^{25}$ Każdej parze skrajnych stwierdzeń przyporządkowano odpowiednio -2 oraz 2 punkty. Neutralny wybór otrzymał wartość 0 , a wybory pośrednie odpowiednio -1 oraz 1 punkt. 
Jednak nie tylko w wymiarze pracy zawodowej, ale również $\mathrm{w}$ innych kontakty z cudzoziemcami wpływają na zmianę opinii o „obcych”. Znalazło to potwierdzenie $\mathrm{w}$ trakcie wywiadów jakościowych $\mathrm{z}$ celowo dobranymi mieszkańcami Poznania. Uczestnicy rozmów wielokrotnie wskazywali na rozdźwięk pomiędzy wcześniejszym osobistym negatywnym a stereotypowym obrazem „obcych” kulturowo przybyszów oraz zmiana tych opinii pod wpływem doświadczeń wyniesionych z kontaktów z cudzoziemcem. Przykładem takiej typowej konwersacji pomiędzy moderatorem i uczestnikiem wywiadu jest rozmowa przeprowadzona z mężczyzną w wieku około 35 lat. Po zapewnieniach respondenta o braku uprzedzeń wobec obcokrajowców z krajów Europy Zachodniej, moderator dopytał o stosunek wobec innych narodowości, uzyskując następującą wypowiedź:

Respondent: No, w akademiku mieszkałem, więc miałem styczność z obcokrajowcami praktycznie z każdego kraju. Z Ukrainy, z Rosji, [...] z całej Afryki...

Moderator: I jak się układały te stosunki?

Respondent: Nie, no bardzo dobrze. Obok mieszkał właśnie obcokrajowiec z Kongo. A większość Polaków myśli: jak Murzyn to śmierdzi. To znaczy, ja też miałem takie odczucia na początku. A później to sympatycznie. No, po prostu dobre, dobre stosunki miałem.

(Wywiad z mężczyzną w wieku około 35 lat, pracownikiem w prywatnej firmie).

W pewnych sytuacjach doświadczenia wyniesione ze spotkań lub wspólnej pracy $\mathrm{z}$ cudzoziemcami moga jednak wzmacniać wcześniejsze stereotypy i uprzedzenia. Właścicielka jednego z poznańskich salonów kosmetycznych w następujący sposób uzasadniła swój stosunek wobec obcych kulturowo przybyszów:

No po prostu, jak ja to mówię, podpalana skóra, podpalana cera, to ja nie wiem. Pracowałam kiedyś z Meksykanami albo Ekwadorczykami. Masakra, masakra! Co to sa po prostu za kłótliwi ludzie! Oni wszyscy muszą mieć tak, jak oni chcą. [...] Zazdroszczą nam tego, że jesteśmy biali, że jesteśmy wykształceni, że jesteśmy w większości, powiedzmy, normalnymi ludźmi. Tak! I oni się źle czują z tym, bo oni są czarną siłą roboczą. Więc oni tam po prostu (pauza) [...] często jest tak, oni myślą że maja najgorzej, że jak coś nie tak, to na białego.

(Wywiad z kobietą w wieku około 35 lat, właścicielką salonu kosmetycznego).

Wydaje się, że w omawianej sytuacji niechęć wobec cudzoziemców była dużo głębsza niż wśród innych uczestników wywiadów i opierała się dodatkowo na uprzedzeniach rasowych. Ponadto na posiadane przez respondentkę stereotypy nałożyły się tendencje do przypisywania obcokrajowcom cech wyraźnie negatywnych, przy jednoczesnej skłonności do przypisywania sobie cech jednoznacznie pozytywnych. 


\section{Wykres 3}

Akceptacja podejmowania przez obcokrajowców pracy w Polsce a ocena ich cech moralnych

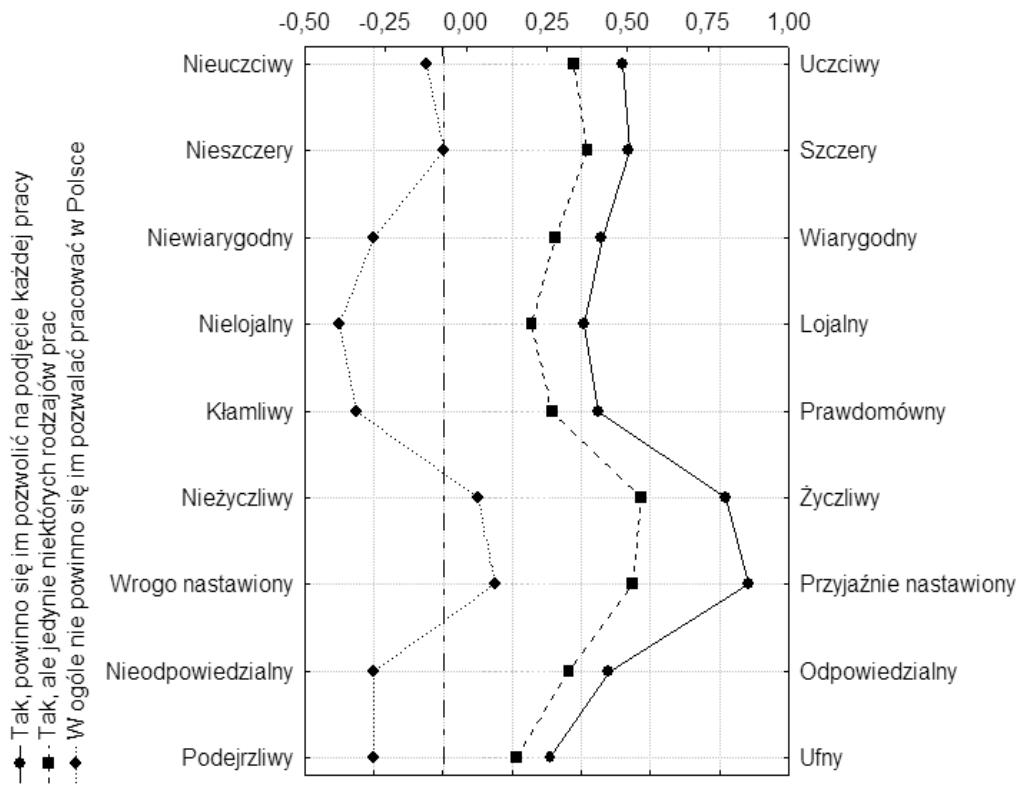

Podobne relacje zachodzące pomiędzy oceną cech moralnych obcokrajowców a akceptacją ich obecności na rynku pracy w Polsce znalazły swoje odzwierciedlenie w ilościowej części badań. Przykład takiej zależności zobrazowany został na wykresie 3.

$\mathrm{Z}$ zaprezentownych na wykresie rozkładów można odczytać, że w kategorii respondentów wyrażających sprzeciw wobec możliwości pracy obcokrajowców w Polsce przeważały osoby przypisujace cudzoziemcom cechy negatywne, inaczej niż w kategorii badanych w pełni lub częściowo akcepujących obecność osób z zagranicy na polskim rynku pracy: tu odsetek respondentów przypisujących cechy moralne, był zdecydowanie wyższy od odpowiedniego odsetka badanych przyporządkowujących ,obcym” cechy amoralne.

\section{POZIOM POCZUCIA ZAGROŻENIA WYRAŻANEGO W ZWIĄZKU Z OBECNOŚCIĄ OBCOKRAJOWCÓW W POLSCE}

Przeprowadzone analizy ukazują zatem, że mieszkańców Poznania charakteryzuje wysoki poziom akceptacji dla obecności obcokrajowców na rynku pracy w Polsce. Niemniej, pomimo gospodarczej otwartości na „obcych”, rejestruje się już pewne przejawy nieufności wobec kulturowo-obyczajowej odmienności przybyszów. Trudno zatem przewidzieć, na ile zauważane obecnie pragmatyczne podejście poznaniaków do możliwości pracy obcokrajowców w Polsce 


\section{Wykres 4}

Grupowanie wskaźników obaw wyrażanych w związku z obecnością obcokrajowców w Polsce

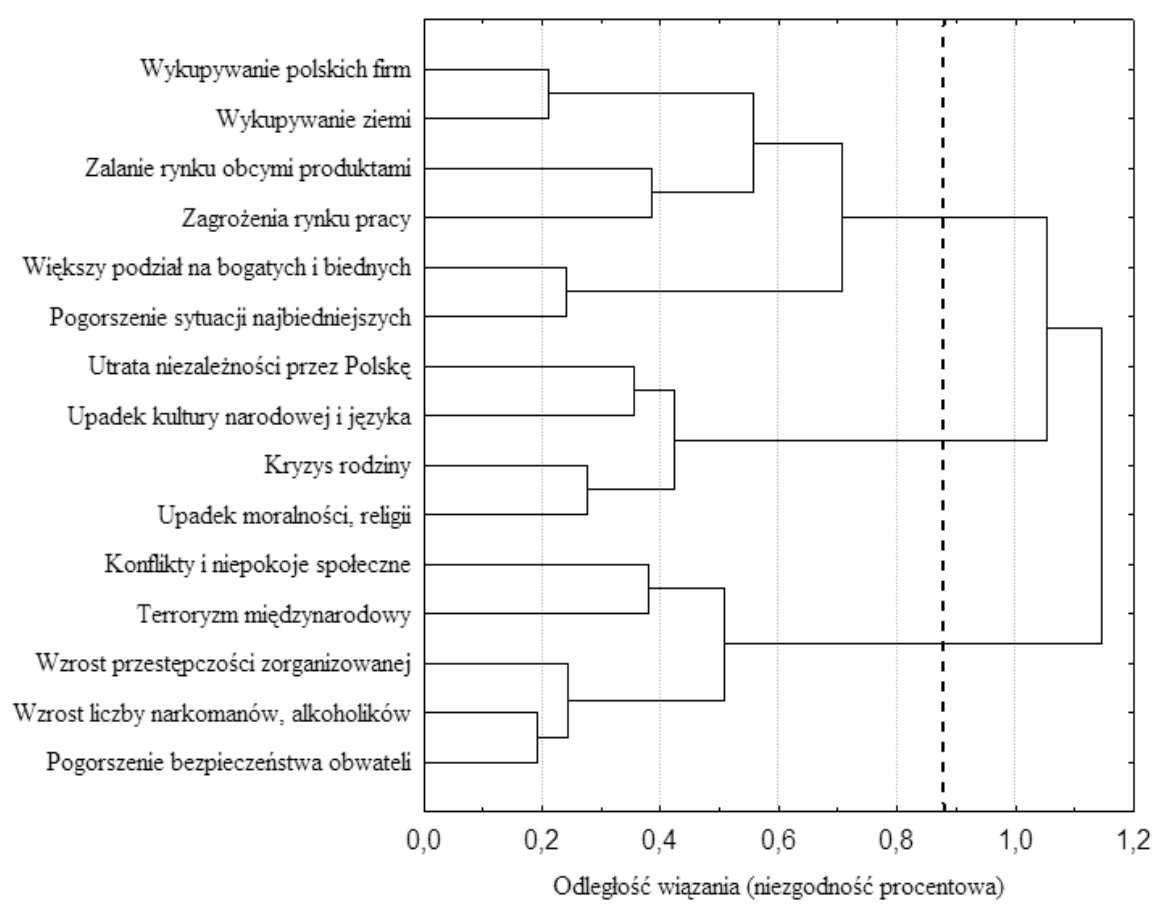

będzie w przyszłości nadal dominować nad ich kulturową zachowawczością. Z tego właśnie względu należałoby zwrócić uwagę także na wyrażany przez mieszkańców Poznania poziom obaw formułowanych w odniesieniu do zagrożeń, jakie mogą się pojawić w wyniku przyjazdu obcokrajowców do Polski, a także monitorowanie tych obaw w przyszłości. Taki element diagnozy występował również w omawianym projekcie badawczym. Respondentom zaprezentowano zestaw piętnastu potencjalnych zagrożeń (por. wykres 4) oraz poproszono o ocenę, w jakim stopniu osobiście obawiają się oni tych spraw ${ }^{26}$.

${ }^{26}$ Pytanie kwestionariuszowe, diagnozujące poziom poczucia zagrożenia wyrażanego przez poznaniaków w związku z napływem obcokrajowców do Polski, oparte zostało na pytaniu oryginalnie skonstruowanym w ramach projektu badawczego ,Wielkopolanie wobec integracji Polski z Unią Europejską"; por. R. Cichocki, P. Cichocki, P. Jabkowski, Europejska świadomość Wielkopolan, Wydawnictwo Fundacji Humaniora, Poznań 2005, s. 68-89. W pierwotnym zamyśle pytanie to miało na celu analizę poziomu wyrażanych obaw w związku z wejściem Polski do UE, a w domyśle - otwarciem granic Polski dla obcokrajowców z krajów Unii Europejskiej. W obecnej formie pytanie ma szerszy sens i dotyczy nie tylko cudzoziemców z państw UE, ale obcokrajowców w ogóle, co wyraźnie sugerowane było respondentom poprzez dynamiczną strukturę kwestionariusza wywiadu. Respondenci oceniali poziom obaw, wybierając jedną z pięciu możliwych odpowiedzi, począwszy od „Zdecydowanie się nie obawiam”, przez „Raczej się nie obawiam”, „Ani się nie obawiam, ani się obawiam”, „Raczej się obawiam”, aż do ,Zdecydowanie się obawiam”. Poszczególnym kategoriom przyporządkowano umowne wagi liczbowe od 1 do 5 . 
Przed zaprezentowaniem rozkładów uzyskanych odpowiedzi poszczególne wskaźniki wymagają wcześniejszego uporządkowania, tak by zmniejszyć liczbę zmiennych koniecznych do analizy. W tym celu wykorzystam statystyczna procedurę analizy skupień ${ }^{27}$, która pozwoli na redukcję wymaganej liczby wymiarów oraz identyfikację pewnych podobnych klas wskaźników obaw ${ }^{28} . \mathrm{Na}$ wykresie 4 przedstawiono rezultat zastosowanej procedury statystycznej. Oś odciętych wykresu ukazuje niezgodności w rozkładach odpowiedzi udzielonych na poszczególne pytania, przy czym odległości te interpretuje się w ten sposób, że im mniejsza jest ich wartość, tym wskaźniki uznaje się za bardziej do siebie podobne ${ }^{29}$. Pionowa przerywaną linią zaznaczono dodatkowo sugerowany statystyczny punkt odcięcia, który pomaga wyznaczyć konieczną do poprawnej analizy liczbę grup wskaźników.

Procedura analizy skupień grupuje piętnaście wyjściowych wskaźników $\mathrm{w}$ trzy odmienne kategorie obaw. W ramach pierwszej $\mathrm{z}$ nich - nazwanej umownie obawami ekonomicznymi -znalazło się sześć wskaźników opisujących obawy o wykupywanie polskich firm oraz ziemi przez obcokrajowców, zalanie rynku obcymi produktami, zagrożenia dla rynku pracy, większy podział na bogatych i biednych oraz pogorszenie sytuacji najbiedniejszych. Druga kategorię stanowią cztery wskaźniki opisujące możliwe zagrożenia dla tradycyjnych wartości społecznych, a także dla kultury narodowej i niezależności państwa. W obrębie tej grupy, nazwanej umownie obawami kulturowo-obyczajowymi, zgrupowano wskaźniki obaw o utratę niezależności przez Polskę, upadek kultury narodowej i języka polskiego, kryzys wartości rodzinnych, wzrost liczby rozwodów, upadek moralności oraz zagrożenia dla religii. Wreszcie trzecią wyodrębnioną tu grupę stanowi pięć wskaźników zagrożeń obejmujących: obawy o możliwe pojawienie się konfliktów i niepokojów społecznych oraz międzynarodowego terroryzmu, wzrost przestępczości zorganizowanej, pogorszenie bezpieczeństwa zwykłych obywateli oraz coraz większa liczbę narkomanów i alkoholików. Ta trzecia klasa zagrożeń określona została jako obawy związane z bezpieczeństwem. Następnie dla tak wyodrębnionych grup zmiennych utworzone zostały odpowiednie skale pomiarowe ${ }^{30}$.

${ }^{27}$ Procedura analizy skupień jest nieparametryczną alternatywą dla analizy czynnikowej; nie wymaga jednak spełnienia ostrych warunków homogeniczności wariancji, normalności rozkładów czy chociażby ilorazowego charakteru pomiaru zmiennych, których wielomianowe dane porządkowe wykorzystane w prezentowanym pytaniu kwestionariuszowym spełniać po prostu nie mogą.

${ }^{28}$ Metodą wiązania wskaźników, umożliwiającą tworzenie klas możliwie się od siebie różniących, jest procedura wiązania pełnego. W tej metodzie odległość pomiędzy skupieniami określana jest przez największą z odległości między dwoma dowolnymi obiektami należącymi do różnych skupień, tzw. najdalszymi sąsiadami.

${ }^{29}$ Miara odległości (różnic pomiędzy wskaźnikami), ze względu na charakter poziomu pomiaru zmiennej oparta została na niezgodności procentowej. Najbardziej ogólnie można powiedzieć, że miara ta służy porównaniu każdej pary wskaźników i ustaleniu odsetka par różnych odpowiedzi. Dla przykładu, jeżeli wartość miary niezgodności procentowej dla wskaźnika obaw o wzrost liczby narkomanów, alkoholików itd. oraz wskaźnik obaw o pogorszenie bezpieczeństwa obywateli wynosi niespełna $20 \%$, to w takim właśnie odsetku odpowiedzi wystąpiły rozbieżności w ocenie poziomu obaw dla tych dwóch typów zagrożeń. Oznacza to również, że dla ponad $80 \%$ wszystkich badanych poznaniaków oba typy zagrożeń identyfikowane były jako podobne.

${ }^{30}$ Wynik skali uzyskiwany jest poprzez uśrednienie wartości wskaźników wchodzących w jej skład, co sprowadza utworzone skale pomiarowe do formatu Likerta. Każda $\mathrm{z}$ trzech skal spełniała 


\section{Wykres 5}

Poziom obaw wyrażanych w związku z obecnością obcokrajowców w Polsce

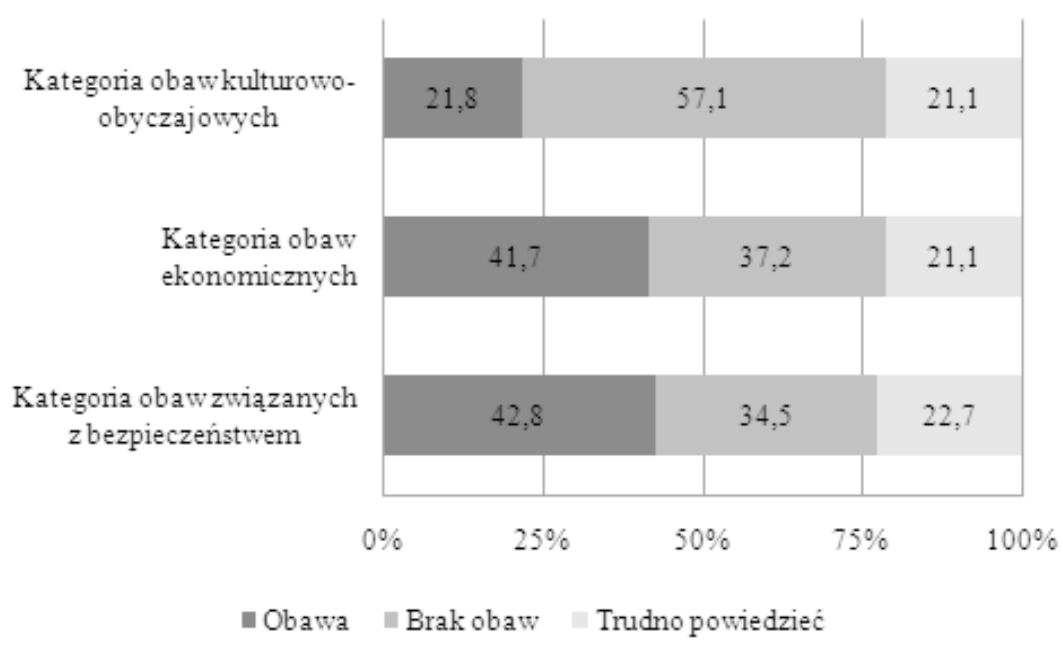

Z zaprezentowanego na wykresie rozkładu można jednoznacznie odczytać, że mieszkańcy Poznania formułuja największe obawy w odniesieniu do kategorii zagrożeń związanych z bezpieczeństwem oraz ekonomicznymi konsekwencjami przyjazdu i osiedlania się obcokrajowców w Polsce. Odsetek respondentów wyrażających obawy zdecydowanie przewyższa, w obu kategoriach zagrożeń, odpowiedni odsetek respondentów daklarujących brak takich obaw. Natomiast w ramach trzeciej grupy wskaźników - związanych z zagrożeniami kulturowo-obyczajowymi - wyraźnie rysuje się dużo niższy poziom deklarowanych obaw. Dominująca grupę stanowią bowiem respondenci wyrażający opinię, że wraz z przyjazdem obcokrajowców do Polski nie będą zagrożone tradycyjnie definiowane wartości oraz niezależność państwa. Obserwacja ta jest interesująca w perspektywie zarejestrowanej wysokiej akceptacji obecności obcokrajowców na rynku pracy oraz jednoczesnej nieufności wobec kulturowej odmienności ,obcych”. Zatem pomimo otwartości poznaniaków na możliwość podejmowania pracy przez przybyszów z innych krajów, widoczny jest jednoczesny wzrost obaw o pogorszenie własnych warunków ekonomicznych, a niskiej akceptacji dla możliwości publicznej ekspresji odmienności kulturowej przez obcokrajowców towarzyszy stosunkowo niski poziom poczucia zagrożeń kulturowo-obyczajowych.

W świetle migracji kompensacyjnych oraz opinii poznaniaków o możliwości osiedlania się i podejmowania pracy przez obcokrajowców szczególnie interesująca wydaje się druga z omawianych kategorii zagrożeń (związana z obawami ekonomicznymi). Zawiera ona bowiem wskaźniki bezpośrednio łączące się z zagrożeniami dla warunków materialnych ludności oraz stabilnością rynku pracy. Uzupełniając opis uzyskanych wyników, przeprowadzę jeszcze analizę

metodologiczne wymogi rzetelności statystycznej $\alpha$-Cronbacha. Dla omawianej w artykule kategorii obaw ekonomicznych wyniosła ona $\alpha=0843$. 
Tabela 1

Społeczno-demograficzne uwarunkowania poziomu obaw ekonomicznych

\begin{tabular}{|l|c|c|}
\hline \multirow{2}{*}{\multicolumn{1}{|c|}{ Parametry modelu regresji }} & \multicolumn{2}{c|}{ Badanie w 2009 r. } \\
\cline { 2 - 3 } & estymator $\beta$ & istotność \\
\hline Płeć (mężczyzna - kod 1) & 0,027 & 0,425 \\
\hline Wiek & 0,021 & 0,204 \\
\hline Wykształcenie - podstawowe (w tym niepełne) & $\mathbf{0 , 1 1 7 * *}$ & 0,037 \\
\hline Wykształcenie - zasadnicze zawodowe & $-0,003$ & 0,947 \\
\hline Wykształcenie - średnie i pomaturalne & ref. & - \\
\hline Wykształcenie - licencjackie oraz wyższe & 0,004 & 0,915 \\
\hline Dochód - bez dochodu & $\mathbf{0 , 2 4 6 * *}$ & 0,011 \\
\hline Dochód - do kwartyla dolnego & ref. & - \\
\hline Dochód - od kwartyla dolnego do kwartyla górnego & $-0,038$ & 0,494 \\
\hline Dochód - powyżej kwartyla górnego & $\mathbf{- 0 , 1 2 2 * *}$ & 0,042 \\
\hline Dochód - odmowa odpowiedzi & $-0,059$ & 0,066 \\
\hline Status zawodowy - osoba pracujacca & $-0,071$ & 0,356 \\
\hline Status zawodowy - uczeń/student & $\mathbf{- 0 , 1 7 1 *}$ & 0,070 \\
\hline Status zawodowy - gospodyni domowa & 0,015 & 0,901 \\
\hline Status zawodowy - emeryt/rencista & 0,015 & 0,857 \\
\hline Status zawodowy - osoba bezrobotna & ref. & - \\
\hline constans & 1,105 & - \\
\hline Współczynnik determinacji R $\mathbf{p}^{2}$ & & $9,8 \%$ \\
\hline
\end{tabular}

* estymator parametru $\beta$ istotny na poziomie 0,1

** estymator parametru $\beta$ istotny na poziomie 0,05

uwarunkowań poziomu wyrażanych obaw ekonomicznych od społeczno-demograficznych cech respondentów. Wykorzystam metodę regresji wielorakiej, przy czym zmienną zależną będzie logarytm naturalny z wartości skali poziomu obaw ekonomicznych ${ }^{31}$. Trzy wartości zmiennych:

1) wykształcenie średnie lub pomaturalne,

2) posiadanie dochodu o wartości nieprzekraczającej kwoty $25 \%$ najniższych dochodów (dochód do kwartyla dolnego),

${ }^{31}$ Analizy regresyjne opierające się na logarytmicznych przekształceniach wartości zmiennej wykorzystuje m.in. H. Domański, rozpatrując mechanizmy zróżnicowania dochodów oraz uwarunkowania poziomu dochodów od poziomu wykształcenia; por. H. Domański, Mechanizmy stratyfikacji $i$ hierarchie spoteczne, w: M. Marody (red.), Wymiary życia spotecznego. Polska na przetomie XX $i$ XXI wieku, Wydawnictwo Naukowe Scholar, Warszawa 2007, s. 67-92. Przekształcenie logarytmiczne ułatwia interpretację parametrów modeli regresyjnych przypisanych określonej kategorii społeczno-demograficznej respondentów, jako dystansu pomiędzy przeciętnym poziomem obaw dla całej próby badawczej a poziomem obaw w danej kategorii osób. 
3) fakt bycia osobą bezrobotną, stanowić będą w modelu analizy tak zwane kategorie odniesienia, pomijane $\mathrm{w}$ analizach regresji, lecz możliwe do odtworzenia poprzez właściwą interpretację wyników ${ }^{32}$.

Zaprezentowane w tabeli wyniki pokazuja, że wyrażane przez mieszkańców Poznania obawy ekonomiczne są istotnie zróżnicowane w zależności od wykształcenia, dochodu oraz statusu zawodowego badanych, nie są z kolei uzależnione od płci oraz wieku respondentów. Istotnie większym poziomem obaw charakteryzują się poznaniacy $\mathrm{z}$ wykształceniem podstawowym (poziom wyrażanych obaw wyższy o 11,7\% od przeciętnego), a także osoby, które nie posiadają dochodu (cechuje ich o $24,6 \%$ większy poziom obaw niż średnio w całej próbie) oraz badani będący osobami bezrobotnymi, którzy wyrażali o ponad $21 \%$ wyższy poziom obaw niż przeciętnie wszyscy respondenci w próbie. Z drugiej strony, istotnie niższy poziom obaw był deklarowany przez badanych o najwyższych dochodach, a także przez uczniów oraz studentów (w pierwszej z kategorii poziom obaw był o $12,2 \%$, a w drugiej o $17,1 \%$ niższy od tego, który zarejestrowano przeciętnie w obrębie całej próby badawczej). Uzyskane zróżnicowania sa interesujące, choć nie zaskakują. Ukazują bowiem, że wyższym poziomem obaw ekonomicznych cechuja się badani, których sytuacja finansowa oraz pozycja na rynku pracy jest najsłabsza. Warto zauważyć również, że osoby o niskim poziomie wykształcenia, bezrobotne oraz te, które nie posiadaja dochodu, jednocześnie wyrażaja wysoki poziom obaw o pogorszenie swoich warunków ekonomicznych oraz większy opór wobec możliwości podejmowania przez obcokrajowców pracy w Polsce. Jednak obie te cechy (akceptacja dla pracy cudzoziemców oraz obawy ekonomiczne) są ze sobą ściśle powiązane ${ }^{33}$.

\section{ZAKOŃCZENIE}

Zaprezentowane $\mathrm{w}$ artykule analizy empiryczne ukazały wysoki stopień przyzwolenia poznaniaków na możliwość podejmowania pracy przez cudzoziemców. Rozkłady odpowiedzi pozostają przy tym zbieżne z wynikami badań na próbach ogólnopolskich, ukazując dominację przekonań akcentujących zgodę na pracę obcokrajowców w dowolnym - wybranym przez nich zawodzie. Potwier-

${ }^{32}$ Ze względu na redundantny charakter kodowania poszczególnych wartości trzech zmiennych niezależnych - wykształcenia, dochodów oraz statusu zawodowego - w postaci zmiennych 0-1, konieczne jest pominięcie w każdym wypadku jednej kategorii wartości. Dla każdej pominiętej kategorii możliwe jest jednak wtórne ustalenie wartości współczynników regresji, która jest liczbą przeciwną sumie wartości współczynników regresyjnych dla pozostałych kategorii ujętych w schemacie analizy regresji (por. ibidem, s. 83). Dla przykładu, wartość estymatora współczynnika regresji dla pominiętej kategorii osób bezrobotnych byłaby równa -[-0,071-0,171+0,015+0,015], czyli w sumie wynosiłaby 0,212 . Wynik ten interpretuje się w ten sposób, że osoby pozostające bez pracy charakteryzują się przeciętnie wyższym o 21,2\% poziomem obaw, niż wynosi przeciętny poziom poczucia zagrożenia w całej próbie.

${ }^{33}$ Współzależność potwierdza test Pearsona $\left(\chi^{2}\right)$. Wartość statystyki testowej wyniosła $\chi^{2}=56,03$ z $d f=4$. Ponieważ poziom istotności statystyki testowej był mniejszy od założonego poziomu istotności wnioskowania równego 5\%, to istnieją przesłanki do przyjęcia hipotezy o współzależności obu cech. 
dziły się również takie ogólne tendencje w postrzeganiu przybyszów, jak wyższy poziom przyzwolenia na podejmowanie pracy przez cudzoziemców wyrażony przez tych badanych, którzy posiadali pozytywne doświadczenia w kontaktach $\mathrm{z}$ obcokrajowcami, czy też zaobserowane relacje pomiędzy opinią o obcokrajowcach a pewnymi cechami społeczno-demograficznych respondentów (na przykład ich wiekiem, wykształceniem czy wielkością dochodu). Niemniej przy akceptacji napływu „obcych”, uwidaczniają się jednak pewne obawy z tym związane. W przeważającej części badani mieszkańcy wyrażali bowiem opinię, że wraz z przyjazdem i osiedlaniem się obcorajowców w Polsce zagrożony może być ład i porządek publiczny, a także ich osobiste interesy ekonomiczne. Równocześnie $\mathrm{z}$ wypowiedzi badanych można było odczytać, że na ich opinię o możliwości podjmownia pracy przez cudzoziemców dużo większy wpływ wywiera przekonanie o pozytywnym oddziaływaniu międzykrajowych imigracji na sytuację rynku pracy w Polsce niż poczucie zagrożenia. Szczególnie silnie podkreślano, że pojawianie się przybyszów jest procesem nieodwracalnym, choćby ze względu na fakt, iż pewne zawody pozostają nieobsadzone przez polskich pracowników.

Brak oporów poznaniaków wobec obecności obcokrajowców na rynku pracy wydaje się znaczącym czynnikiem wzmacniającym potencjał aktywnego przystosowania się do zmian wywołanych procesem integrującej się Europy. Taka postawa, a precyzyjniej - deklarowana otwartość na „obcych”, jest korzystna przede wszystkim $\mathrm{w}$ kontekście zmian zachodzących $\mathrm{w}$ strukturze migracji kompensacyjnych do Polski. W tym względzie czynnikiem wzmacniającym poziom innowacyjności i swego rodzaju szansa rozwojową jest coraz większy udział w rynku pracy osób z krajów „,starej” UE15, obejmujących najczęściej stanowiska wysoko wykwalifikowanej kadry zarządzającej. W wypadku tego rodzaju migracji zawodowych mamy do czynienia z przekazywaniem nowych i/lub innowacyjnych stylów pracy, kultur organizacyjnych, sposobów organizacji pracy oraz technik zarządzania personelem firmy. Stosunkowo wysoki poziom akceptacji i otwartości na takie nowe style pracy połączony $z$ ich pozytywny obrazem powodować może kulturowe przenoszenie nowych form organizacji na lokalny rynek pracy.

Opinie poznaniaków na temat możliwości osiedlania się obcokrajowców w Polsce oraz podejmowania przez nich pracy zarobkowej sa jednak przede wszystkim odzwierciedleniem cech przypisywanych tradycyjnej mentalności mieszkańców Poznania. Dochodzi przy tym do wyraźnego rozdźwięku pomiędzy dwoma podstawowymi komponentami tej lokalnej mentalności: $\mathrm{z}$ jednej strony - gospodarczą otwartością, z drugiej - kulturowo-obyczajową zachowawczością. Wyrazem takiego dwubiegunowego charakteru opinii poznaniaków wyrażanych $\mathrm{w}$ stosunku do cudzoziemców jest wysoki poziom akceptacji obecności przybyszów z państw Europy Zachodniej oraz Ameryki Północnej, niższy poziom społecznego przyzwolenia na możliwość osiedlania się cudzoziemców z krajów Dalekiego Wschodu, państw muzułmańskich, republik kaukaskich, czy też krajów ,,czarnej” Afryki, a także - niezależnie od pochodzenia przybyszów - wysokie oczekiwania asymilacji względem lokalnej 
tożsamości i obyczajowości. Wprawdzie pragmatyczna postawa gospodarczej otwartości poznaniaków przeważa, przynajmniej na razie, nad ich kulturowo-obyczajową zachowawczością, ale w przyszłości nie można wykluczyć dominacji oporu wobec cudzoziemców z krajów definiowych jako obce kulturowo.

\author{
dr Piotr Jabkowski \\ Uniwersytet im. Adama Mickiewicza w Poznaniu \\ pjabko@amu.edu.pl
}

\title{
OPINIONS AMONG POZNAN'S INHABITANTS CONCERNING THE PRESENCE OF FOREIGNERS ON THE LABOUR MARKET IN VIEW OF REPLACEMENT MIGRATION TO POLAND
}

\begin{abstract}
Summary
The analysis presented in the paper focuses on the attitudes of Poznan inhabitants towards the presence of foreigners on the Polish labour market. The presented results have been derived from a research project: 'The level of trust among Poznan inhabitants towards foreigners and its sources,' which was conducted from October 2009 to September 2010. It was based on two measurements: (i) questionnaire interviews (PAPI) conducted on a random sample of Poznan inhabitants (436) and (ii) more detailed interviews with selected inhabitants who have come in contact with foreigners living in Poland.

The features typically attributed to the mentality of Poznan inhabitants determine the attitudes with respect to the migration of foreigners to Poland and their taking of jobs. There is a definite discrepancy between the two components of this Poznan mentality characterised by economic openness on the one hand, and resistance to change in the areas of culture and customs on the other. The expression of this bipolar nature of Poznan inhabitants attitudes with respect to foreigners is the high level acceptance of the presence of workers coming from Western Europe and North America, and a lower level of social acceptance of the immigration from the Far East, Muslim states, Caucasian republics, or the countries of sub-Saharan Africa, as well as - irrespective of the country of origin - a high level of expectations with respect to the assimilation to the local identity and cultural rites. Although the pragmatic attitude of economic openness among Poznan inhabitants currently prevails, it cannot be excluded that in the future it will be replaced by the resistance towards accepting foreigners originating from countries defined as culturally 'other.'
\end{abstract}

